Relations industrielles

Industrial Relations

\title{
Wardell, Mark, Thomas L. Steiger and Peter Meiksins, editors, Rethinking the Labor Process
}

\section{Louise Clarke}

Volume 55, numéro 3, 2000

URI : https://id.erudit.org/iderudit/051346ar

DOI : https://doi.org/10.7202/051346ar

Aller au sommaire du numéro

Éditeur(s)

Département des relations industrielles de l'Université Laval

ISSN

0034-379X (imprimé)

1703-8138 (numérique)

Découvrir la revue

Citer ce compte rendu

Clarke, L. (2000). Compte rendu de [Wardell, Mark, Thomas L. Steiger and Peter Meiksins, editors, Rethinking the Labor Process]. Relations industrielles /

Industrial Relations, 55(3), 560-562. https://doi.org/10.7202/051346ar

Tous droits réservés @ C Département des relations industrielles de l'Universite Laval, 2000
Ce document est protégé par la loi sur le droit d'auteur. L’utilisation des services d'Érudit (y compris la reproduction) est assujettie à sa politique d'utilisation que vous pouvez consulter en ligne.

https://apropos.erudit.org/fr/usagers/politique-dutilisation/ 


\section{Rethinking the Labor Process}

edited by Mark Wardell, Thomas L. Steiger and Peter MeIKSinS, Albany:

State University of New York Press, 1999, 276 p., ISBN 0-7914-4282-9.

This collection of essays was published to mark the $25^{\text {th }}$ anniversary of the publication of the seminal work in labour process theory, Braverman's Labor and Monopoly Capital (1974). But its purpose, according to the editors, is to build on his work and subsequent debates to show the continuing relevance of labour process theory to the contemporary study of work and the inequalities produced. In the first essay, Wardell does a good job of presenting an overview of Braverman's ideas and the criticisms of them. The labour process itself is defined as "a means by which objects, people, tools, knowledge, and tasks are organized so that they are transformed into different objects or services having some value for others" (p. 4). Braverman argued that, within the context of the modern employment relationship, there is a structural necessity for management to control the labour process so that capital can maximize its profit. The primary means of this control is Taylorism and, as a result of this, labour becomes progressively degraded through a deskilling of work (separation of conception and execution). Wardell cites five major criticisms of Braverman's highly scrutinized work: deskilling as the only form of control, the assumption of a linear degradation of work, the absence of the subjective (worker awareness and resistance), a focus on the shopfloor almost to the exclusion of outside influences, and the assumption that there was really only one labour process across industries.

Each of the other nine essays in the collection addresses several of these issues. The diversity of empirical focus and methods, the range and level of theoretical debate, and the high quality of several of the individual chapters in this book all indicate the continuing relevance of labour process theory and make the book worth reading. At the same time, I could not help thinking that the whole was less than the sum of the parts. The editors provide the barest of structural development and no thematic commentary on the findings, which is frustrating given the diversity and sometimes contradictory findings. They state that the final essay by Smith and Thompson is meant as a "capstone" chapter and, while it is the most comprehensive and compelling essay in the collection, the authors' purpose was not to comment on the other essays. Given this situation, I will present an overview of the chapters and then return to an assessment in the context of the final essay.

The eight primarily empirical essays are ostensibly paired by theme. The first theme is recent trends in management strategies. Kraft focuses on management's new process-centred controls: continuous improvement for routine processes, total quality management for non-routine situations, and business process re-engineering for radical restructuring. He argues that these new strategies are, contrary to Taylorism, dissolving the distinctions between conception and execution. Nevertheless, the end result is the same: "Managers can control [a broad range of] value-adding workers by making everyone standardize, speed up, measure, monitor, and control his or her own work." (p. 27) Burris also believes that Taylorist control has been superseded, but through a different mechanism and with different effects. She claims that computerized production and information technologies have created "technocratic control," amplifying the polarization between conception and execution, expert and nonexpert workers. In my opinion, this was one of the weaker essays, but its contradictory findings still merit comment and further investigation. 
The second pair of essays focus on changes in office work, particularly for workers in non-standard jobs. Rogers' study using participant observation and in-depth interviews among temporary clerical workers was very interesting. She reports material and ideological deskilling, that is, many workers feel that their skills are underutilized, but even where there is skill upgrading, they are not remunerated for it. Employers' discriminate on the basis of "the look" which divides workers by appearance, gender, race and class, and makes a mockery of equality legislation. Greenbaum's comparative analysis of clerical, technical and professional office workers contains some of the same themes as Kraft's analysis. Increased standardization of product for all of these workers, as well as the design principles of coordination and communication of the technical infrastructure, result in the integration rather than separation of tasks, and the broadening rather than specializing of job responsibilities. Nevertheless, wages actually decrease due to work intensification and heightened competition among labour redivided by time, place and contract status - a new "virtual reserve army."

The third pair deal with themes of control and resistance in the auto industry and highlight influences beyond the shopfloor. Gartman develops a critique of Braverman's failure to consider the subjective within the labour process. $\mathrm{He}$ stresses the role of contradictions, not just within mass production, but also between it and mass consumption in shaping control and resistance. Isaac and Christianson propose alternatives to Braverman in five specific areas: the concept of labour itself (subjectivity), the view of time, workplace cultures, the importance of relations beyond the point of production, and research method. They go on to illustrate their theoretical framework with a very interesting analysis of several cases of worker resistance, most notably the Lordstown strike of 1972.
The final pair of essays showcase quantitative analysis of the value of labour. Geschwender and Geschwender argue that declines in both occupational sex segregation and gender earnings inequality, based on U.S. data in 1980 and 1990 , do not support Braverman's contention that the technical division of labour is determinative. Instead, social activism has made a difference through equity legislation and changes in the social division of labour (cf. Rogers). Steiger's analysis of U.S. labour data (1950-1990) shows, as predicted, that labour's share of value and of income have declined in most industrial sectors but, contrary to expectation, skills have increased in most sectors. This suggests that skills and the value of labour are, to a degree, independent (see Greenbaum and Rogers). The precipitous decline in unionization is noted in the statistics, but is ignored in the analysis.

Smith and Thompson assess the situation on "practical" issues of the labour process, namely skills and control, as well as on the "theoretical" issues of subjectivity, class and national-international dimensions. New production systems do reflect an important change from Taylor's strict separation of conception and execution, creating new skill sets (see Kraft, Greenbaum and Steiger vs. Burris), and do rely on enhanced self-control and computer monitoring. Such changes may refute Braverman, but not the core argument of labour process theory that capital is forced to constantly modify its methods to extract value. On the theoretical issues, the authors develop a much deeper analysis than any of the other authors, although Isaac and Christianson make many similar points. Regarding the subjective in the labour process, neither the postmodernist preoccupation with individual "identity work" nor the Foucauldian preoccupation with the technical and social "panopticon" is the way forward since they detract from collective (class) issues and how active resistance is practised. Regarding class, they argue that 
society remains divided between capitalists and workers, but that relations in the labour process have changed as capital has re-asserted control over managers through standardization and casualization, for example. Finally, the dynamic tension between pressures for convergence and divergence, nationally and internationally, according to sector and even corporation, must be taken into account in assessing labour processes, not process.

In sum, this book does, unfortunately, reflect the weaknesses of poorly edited collections: variable quality of the individual contributions and a lack of explicit thematic development and integration. Fortunately, it does convey the relevance of labour process theory, albeit an expanded and more nuanced version than Braverman's. The excellent essay by Smith and Thompson will provide scholars interested in critical traditions, not just labour process theory, with many ideas for building upon the contributions of the other essays.

Louise Clarke

University of Saskatchewan

\section{Strategic Human Resource Management : A Reader \\ sous la direction de Christopher MABEY, Graeme SALAMAN et John STOREY, Londres : Sage Publications en association avec The Open University Busi- ness School, 1998, 334 p., ISBN 0-7619-6032-5 et ISBN 0-7619-6033-3 (pbk.).}

La gestion stratégique des ressources humaines est un sujet brûlant d'actualité. De nombreux auteurs ont tenté de l'approfondir pour finalement lui attribuer des épithètes différentes qui bien souvent ne semblaient pas traduire la même réalité. C'est ainsi que la gestion stratégique des ressources humaines fut tour à tour assimilée à un modèle à rendement élevé, à la gestion renouvelée des ressources humaines, à la nouvelle gestion des ressources humaines et à bien d'autres choses encore. Le mérite indéniable de ce livre est de rendre compte de la diversité du questionnement, des réponses et des perspectives utilisées actuellement par différents auteurs pour définir ce qu'est la gestion stratégique des ressources humaines.

Constitué de contributions diverses publiées dans des revues telles que Journal of Management Studies, British Journal of Management, Work, Employment and Society, Human Resource Management Journal, The International Journal of Human Resource Management, California Management Review et Human Resources Management, pour ne nommer que celles-là, ce recueil de textes inclut aussi des parties de livres tirées d'ouvrages comme The Mutual Gains Enterprise, Managing Human Resources and Industrial Relations, Experiencing Human Resource Management et Manufacturing the Employee. Regroupant au total vingt contributions séparées en quatre parties qui sont à chaque fois présentées et commentées par Mabey, Salaman et Storey, ce volume est celui qui est prescrit pour le module de gestion des ressources humaines du programme de MBA offert par The Open University Business School. Le volume s'adresse ainsi donc à un public qui possède déjà certaines notions de base en gestion des ressources humaines et qui souhaite approfondir et nuancer sa compréhension de l'objet d'étude.

Le texte d'introduction à l'ouvrage, intitulé «Strategic Human Resource Management: The Theory of Practice and the Practice of Theory ", est tout simplement exquis. Les auteurs débutent leur contribution en nous rappelant que la gestion stratégique des ressources 